\title{
若齢犬に生じた皮虔型 $\mathrm{B}$ 細胞リンパ腫
}

\begin{tabular}{|c|c|c|c|}
\hline 田村一朗 ${ }^{11}$ & 藤田桂一 ${ }^{1,3)}$ & 岡村 優 ${ }^{11}$ & 花田幸子 ${ }^{1)}$ \\
\hline & 三ツ村麻美 ${ }^{1)}$ & 山村穂積 2.3) & 酒井健夫 ${ }^{3)}$ \\
\hline
\end{tabular}
1) フジ夕動物病院（テ362-0074 上尾市春日 1-2-53）
2）北川動物病院（干 174-0072 東京都板橋区南常盤台 1-39-1）
3）日本大学生物資源科学部（广 252-0813 藤沢市亀井野 1866）

(1999年 8 月 16 日受付 $\cdot 2000$ 年 9 月 11 日受理)

要約

2 歳の雑種雄犬の体幹背部および腹部の皮膚表面に径 $2 \sim 4 \mathrm{~cm}$ の多数の腫瘤を認めた。病理組織学的検査, 免疫組織 化学的検査, 細胞化学的検查㧍よび表面抗原マーカーの検索の結果, B 細胞由来の皮膚型リンパ腫の非表皮向性型と骖 断された。—キーワード：B細胞リンパ腫, 皮膚型リンパ腫, 犬。

日獣会誌 54，208～211 (2001)

リンパ腫は,リンパ節, 肝臓, 脾臓などの内臓諸臓器 に原発するリンパ系腫瘍で，犬では中年齢〜高齢犬に好 発し，性差は認められない $[1]$ 。本疾患は，発生部位に よって多中心型，消化器型，縦隔型および皮虚型に分類 され，その臨床症状は発生部位や個体によって多岐にわ たり，最終的に患音は死亡する[1]。リンパ腫の発生 は, 若齢犬ではまれであり，2歳以下の犬での皮䖉型り ンパ腫の発生率は $5 \%$ 以下とされている [3].

今回，比較的進行の速い皮膚型リンパ腫を発症した2 歳の犬において, 細胞学的検查, 病理組織学的検査, 免 疫組織化学的検査, 細胞化学的検査, さらにフローサイ トメトリーによる細胞表面抗原の検索を笑施し，本症例 の腫瘍細胞の特徵を明らかにした。

$$
\text { 症例 }
$$

症例は, 体重 $16 \mathrm{~kg}$ の 2 歳の雑種雄犬で, 2 週間前よ り体幹背部および腹部，四肢に多数の腫畋形成を認めた ので来院した。

初診時の一般臨术検査所見では, 体温は $38.7^{\circ} \mathrm{C}$, 皮 䖉表面に径 $2 \sim 4 \mathrm{~cm}$ の赤紫色の腫嵧を多数認めた以外 には，異常は認めなかった。

初診時の一般血液検査所見では, 白血球数の軽度増加 $(15,900 / \mu l)$ 以外は著変はみられなかった（表 1$)$ 。また $23 \mathrm{G}$ 注射針 ${ }^{a)}$ を用いた細胞診では，血液成分に混じて多 数の川形細胞が認められた。これらの細胞は核クロマチ ン結節に乏しい幼若な類门形核と好塩基性の狭い細胞質 を有する前リンパ球あるいはリンパ芽球で, 皮膚型リン
パ腫が示唆された（図1).

1 週間後の再来院時には皮䖉表自の腫瘤は，大きさな らびに数を増しており(汹2), 軽度の元気消失, 食欲不 振がみられた。再来院時の一般血液および血液化学検査 所見に者変はみられなかった（表1).胸部扔よび腹部X 線検查所見でも著変は認められなかったが, 胸部背腹像 において一部にX線不透過像が認められ，形態，大き さ，部位などから皮膚病変であると判断された。さらに

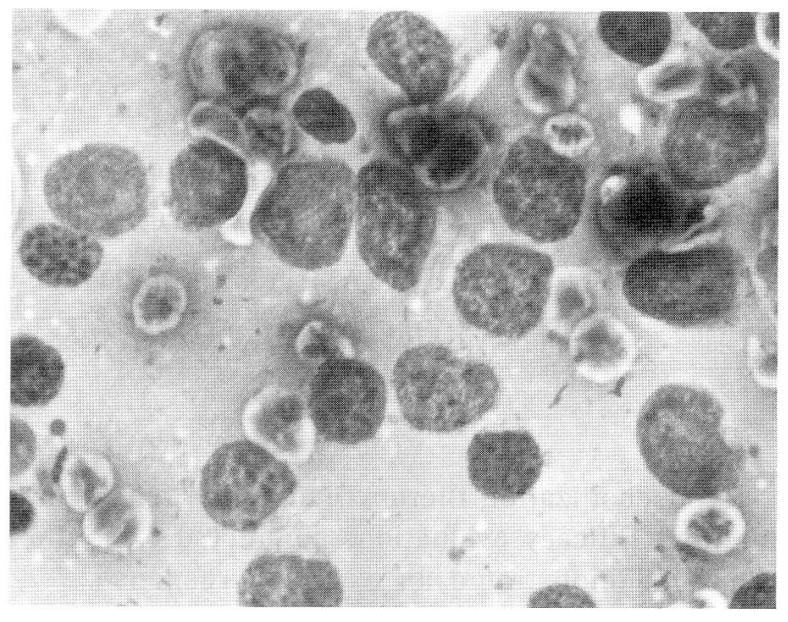

図 1 皮虐型 $\mathrm{B}$ 細胞リンパ腫罹患犬に抢ける初診時の皮膚 表面腫瘤の細胞診所見(ライトギムザ染色 $\times$ 1,000)，核クロマチン結節に㐋しい幼若な類円形核 と好塩基性の狭い細胞質を有する前リンパ球あるい はリンパ芽球が認められる。

a) JMS 注射針 $23 \mathrm{G}$, ジェイ・エム・エス, 広島.

\footnotetext{
$†$ 連絡責任者：田村一朗（フジタ動物病院） 
表1 皮膚型 $\mathrm{B}$ 細胞リンパ腫罹患犬における初診時および 第 8 病日の一般血液・血液化学検査所見

\begin{tabular}{|c|c|c|}
\hline 検査項目 & 初 診 時 & 第 8 病日 \\
\hline \multicolumn{3}{|l|}{ 一般血液 } \\
\hline 赤 血 球 数 & $8.03 \times 10^{6} / \mu l$ & $7.14 \times 10^{6} / \mu l$ \\
\hline 赤血球容積率 & $48.8 \%$ & $45.3 \%$ \\
\hline ヘモグロビン & $17.7 \mathrm{~g} / \mathrm{d} l$ & $16.2 \mathrm{~g} / \mathrm{d} l$ \\
\hline 平均赤血球容積 & $61 \mathrm{fl}$ & $61 \mathrm{fl}$ \\
\hline $\begin{array}{l}\text { 平均赤血球色素 } \\
\text { 濃度 }\end{array}$ & $36.3 \%$ & $35.8 \%$ \\
\hline 血 小板 数 & $37.5 \times 10^{4} / \mu l$ & $44.6 \times 10^{4} / \mu l$ \\
\hline 白血球 数 & $15,900 / \mu l$ & $10,200 \times \mu l$ \\
\hline 好 塩 基 球 & $0 / \mu l$ & $0 / \mu l$ \\
\hline 好 酸 球 & $954 / \mu l$ & $1,326 / \mu l$ \\
\hline リンパ球 & $2,862 / \mu l$ & $2,040 / \mu l$ \\
\hline & $318 / \mu l$ & $204 / \mu l$ \\
\hline 桿状核好中球 & $636 / \mu l$ & $306 / \mu l$ \\
\hline 分葉核好中球 & $11,130 / \mu l$ & $6,324 / \mu l$ \\
\hline \multicolumn{3}{|l|}{ 血液化学 } \\
\hline \multicolumn{2}{|c|}{$\begin{array}{l}\text { アスパラギン酸アミノトランス } \\
\text { フェラーゼ }\end{array}$} & $25 \mathrm{U} / l$ \\
\hline \multicolumn{2}{|c|}{$\begin{array}{l}\text { アラニンアミノトランス } \\
\text { フェラーゼ }\end{array}$} & $33 \mathrm{U} / l$ \\
\hline \multicolumn{2}{|c|}{ アルカリホスファターゼ } & $72 \mathrm{U} / l$ \\
\hline \multicolumn{2}{|l|}{ 総ビリルビン } & $<0.2 \mathrm{mg} / \mathrm{d} l$ \\
\hline \multicolumn{2}{|l|}{ 総コレステロール } & $121 \mathrm{mg} / \mathrm{d} l$ \\
\hline \multicolumn{2}{|l|}{ 血漿総蛋白量 } & $6.9 \mathrm{~g} / \mathrm{d} l$ \\
\hline \multicolumn{2}{|l|}{ 血液尿素窒素 } & $25 \mathrm{mg} / \mathrm{d} l$ \\
\hline \multicolumn{2}{|l|}{ クレアチニン } & $0.9 \mathrm{mg} / \mathrm{d} l$ \\
\hline \multicolumn{2}{|l|}{ グルコース } & $119 \mathrm{mg} / \mathrm{d} l$ \\
\hline \multicolumn{2}{|l|}{ ナトリウム } & $137 \mathrm{mmol} / \mathrm{l}$ \\
\hline \multicolumn{2}{|l|}{ カリウ ム } & $3.9 \mathrm{mmol} / \mathrm{l}$ \\
\hline \multicolumn{2}{|l|}{ クロ ル } & $106 \mathrm{mmol} / \mathrm{l}$ \\
\hline
\end{tabular}

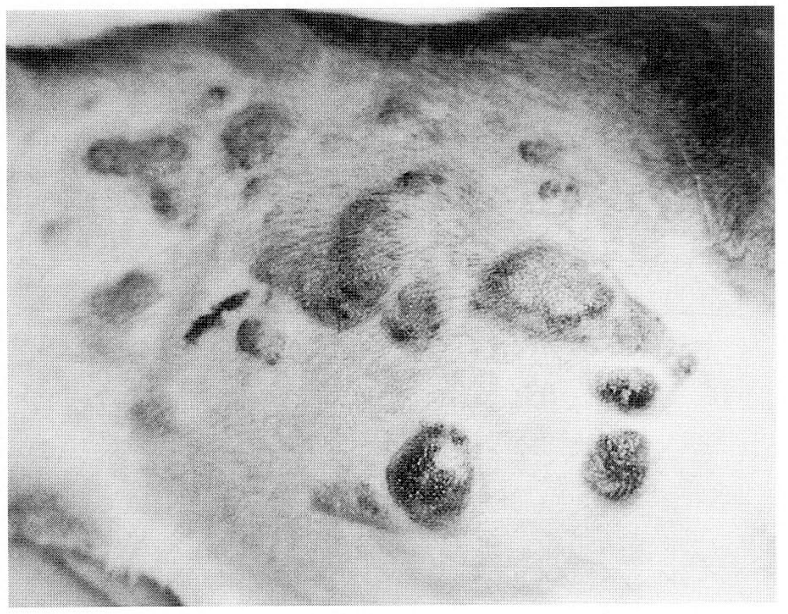

図 2 第8病日の剪毛後の皮膚表面の腫瘤．体幹背部䇽よ び腹部に多数の赤紫色の腫瘤を認める.

b) 抗ビメンチン抗体, DAKO, 京都.

c) 抗 S-100 蛋白抗体, DAKO, 京都.

d) 抗リゾチーム抗体, DAKO, 京都.

e) 抗 $\alpha 1$-アンチトリプシン抗体, DAKO, 京都.

f）抗 $\alpha 1$ 1-アンチキモトリプシン抗体，DAKO，京都.

g) 抗サイトケラチン抗体, DAKO, 京都.

h）抗ヒス夕ミン抗体AB134, ケミコン, U.S.A.

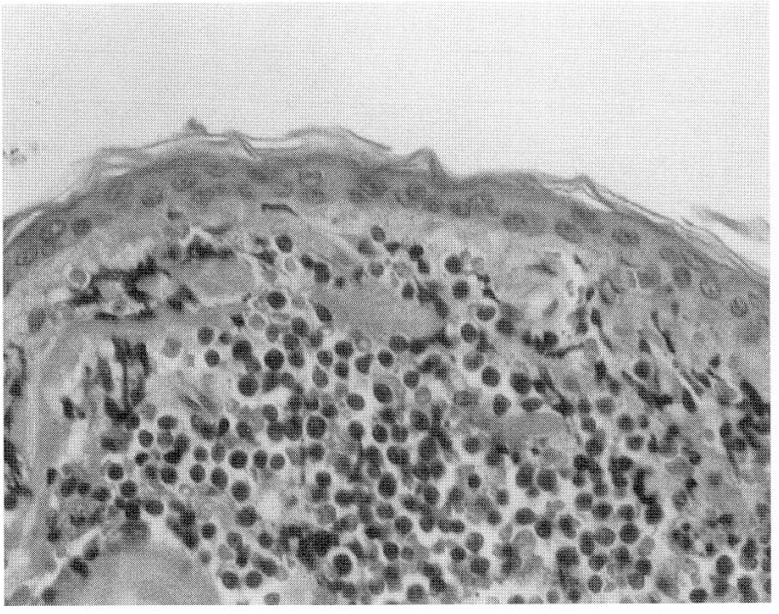

図 3 外科的に切除した皮膚表面の腫瘤の病理組織像.表 皮直下から真皮深層にかけて腫瘍細胞の増殖が認め られる $(\mathrm{HE}$ 染色 $\times 100)$.

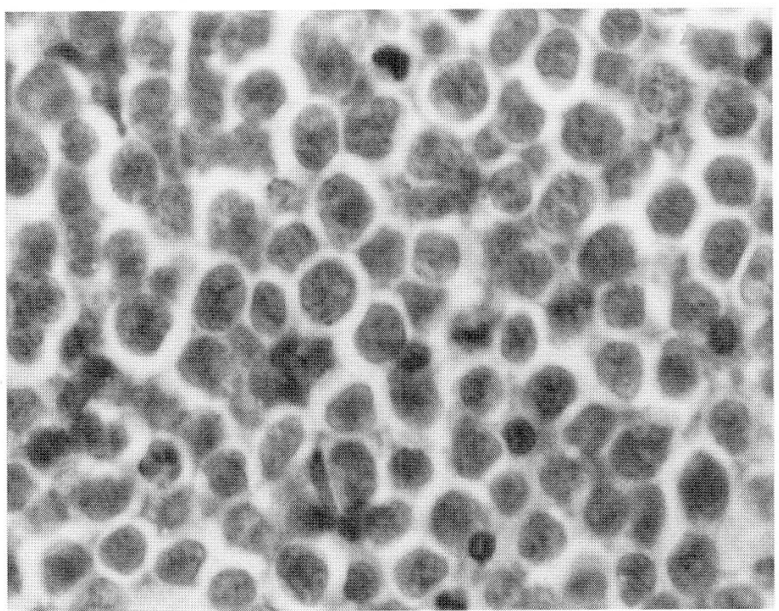

図4 外科・的に切除した皮虐表面の腫瘤の病理組織像. 中 〜大型のリンパ系細胞から構成され，核クロマチン 結節に乏しい類円形核と好塩基性の狭い細胞質を有 している（HE染色 × 400）。

確定診断のため, 一部の腫瘤を外科的に切除し, 病理組 織学的検查, 免疫組織化学的検查, 細胞化学的検查拧上 びフローサイトメトリーによる細胞表面抗原の検索を実 施した。

病理組織学的検查所見では, 表皮直下から真皮媣層に かけて腫崵細胞の増殖が観察された。真皮内に存在する 細胞はご慢性の増殖を示し，中〜大型のリンパ系の細胞 から構成されていた。これらの腫焬細胞は核クロマチン 結節に忘しい類円形核と好塩基性の狭い細胞質を有し， 表皮抒よび毛包への浸潤傾向は認められず，皮膚型リン パ腫の非表皮向性型と判定された（図 $3 ， 4$ ）。

免疫組織化学的検査はパラフィン切片を用いて, ビメ ンチン ${ }^{b}$, S-100 タンパク ${ }^{c}$, リゾチーム ${ }^{\mathrm{d}}, \alpha 1^{-}$アンチ トリプシン ${ }^{\mathrm{e})}, \alpha 1^{-}$アンチキモトリプシン ラチン ${ }^{g}$ ，ヒスタミン蚁対するモノクローナル抗体を 
若齢犬に生じた皮虐型 $\mathrm{B}$ 細胞リンパ腫

\begin{tabular}{|c|c|c|}
\hline マーカー & 検査項目 & 測定值 (\%) \\
\hline \multirow[t]{7}{*}{ T 細胞系 } & $\mathrm{CD} 3$ & 1.9 \\
\hline & $\mathrm{CD} 4$ & 0.3 \\
\hline & $\operatorname{CD} 8 \alpha$ & 2.5 \\
\hline & $\mathrm{CD} 8 \beta$ & 2.0 \\
\hline & $\operatorname{TCR} \alpha \beta$ & 2.1 \\
\hline & $\operatorname{TCR} \gamma \delta$ & 0.5 \\
\hline & Thy 1 & 61.3 \\
\hline \multirow[t]{3}{*}{ B 細胞系 } & $\mathrm{CD} 21$ & 0.6 \\
\hline & $\operatorname{Ig} G$ & 50.0 \\
\hline & $\operatorname{IgM}$ & 39.0 \\
\hline \multirow[t]{10}{*}{ その他 } & MHCclass II & 31.6 \\
\hline & $\mathrm{CD} 18$ & 3.3 \\
\hline & $\mathrm{CD} 45$ & 98.0 \\
\hline & CD45RA & 74.8 \\
\hline & CD11a & 1.6 \\
\hline & $\mathrm{CD} 11 \mathrm{~b}$ & 0.3 \\
\hline & $\mathrm{CD} 11 \mathrm{c}$ & 0.6 \\
\hline & CD1a & 0.4 \\
\hline & $\mathrm{CD} 1 \mathrm{c}$ & 0.4 \\
\hline & $\mathrm{CD} 49 \mathrm{~b}$ & 8.9 \\
\hline
\end{tabular}

使用し， $\mathrm{ABC}$ 法により実施した。本症例は，ビメンチ ン陽性, S-100 タンパク陰性, リゾチーム院性, $\alpha 1-$ ア ンチトリプシン陰性， $\alpha 1$-アンチキモトリプシン院性, サイトケラチン陰性, ヒスタミン陰性であった。

摘出腫瘤のスタンプ標本を用いた腫瘍細胞の細胞化学 的検査では，ペルオキシターゼ㓌性，アルカリ性ホスフ アターゼ陰性, 酸性ホスファターゼおよび非特異エステ ラーゼでは微細顆粒状に弱陽性であった.

さらに腫瘍細胞に各種モノクローナル抗体（抗 CD8 抗体 ${ }^{\mathrm{i})}$, 抗 CD 4 抗体 ${ }^{\mathrm{i})}$, 抗 CD5 抗体 ${ }^{\mathrm{k})}$, 抗 $\operatorname{IgG}$ 抗体 ${ }^{1)}$, 抗 $\operatorname{Ig} M$ 抗体 $^{\mathrm{m})}$ ) を用いたフローサイトメトリーによる表 面抗原マーカーの検索を実施したところ， T細胞系のマ 一カーが低值を，そして表面イムノグロブリンが高い陽 性率を示し, 本症例の腫瘍細胞はB 細胞由来と判定され た（表2）.

以上，本症例の皮膚腫瘤は, $\mathrm{B}$ 細胞由来の皮膚型リン パ腫の非表皮向性型と確定診断された。なお本症例は， 飼い主の希望により，化学療法は実施せず抗生物質の投 与のみ行った。第 90 病日に体表面のリンパ腫の炎症の 激化，元気・食欲の低下，さらには下痢および嘔吐を認 め, 飼い主の強い希望により安楽死の処置をとった。

i) 抗CD8 抗体 MAC1039G, Serotec, U.S.A

j) 抗 CD 4 抗体 MAC1038F, Serotec, U.S.A.

k) 抗 CD5 抗体 MAC1037F, Serotec, U.S.A.

1) 抗 IgG 抗体55310, Cappel, U.S.A.

m) 抗 IgM 抗体55313, Cappel, U.S.A.
考察

リンパ腫は犬によくみられる腫瘍の1つであり，年間 発生率は犬 100,000 頭あたり 30 頭と推定されている [2]. 罹患犬の平均年歯令は $6 \sim 7$ 歳であり，6 力月齢から 15 歳にまでおよぶ [10]. そのうち皮膚型リンパ腫は犬 のリンパ増殖性腫瘍の病態としては一般的ではなく, リ ンパ腫罹患犬の $6.3 \%$ と報告されている $[9]$ ，さらに，2 歳以下の犬での皮膚型リンパ腫の発生率は，皮膚型リン パ腫罹患犬の約 $5 \%$ あ゙あ [3]. したがって今回遭遇し た症例は 2 歳であり，まれであると判断された.

本症例は初診時に白血球数の軽度増加を認めたもの の，種々の検査でも著変が認められなかったが，第 90 病日には元気・食欲の低下および皮膚表面のリンパ腫の 炎症の激化, さらには嘔吐ならびに下痢が認められるよ うになった進行の速いリンパ腫であった。

本症例は初診時の細胞学的検査で, 皮膚型リンパ腫の 可能性が示唆されたため，1 週間後に皮膚表面の腫瘤を 外科的に切除し, 病理組織学的検査, 免疫組織化学的検 査, 細胞化学的検査およびフローサイトメトリーによる 細胞表面抗原の検索を実施した。本症例の摘出腫瘤は， 免疫組織化学的検査の実施により, 皮虐に発生する独立 円形細胞腫瘍である組織球腫，肥満細胞腫およびメラノ ーマは除外され, 細胞化学的検査により, リンパ系細胞 腫瘍であることが示唆された $[8]$. さらにフローサイト メトリーによる細胞表面抗原の検索では，腫瘍細胞は Thy 1 抗原以外は T 細胞系のマーカーが低值を示し, 表 面イムノグロブリンが高い陽性率を示した. Thyl抗原 はさまざまな組織（脳, 腎臟, 甲状腺）や，末梢 $\mathrm{T}$ 細 胞, 胸線細胞, 単球, 好酸球, さらに骨髄でのリンパ球 の早期発育ステージでも発現するため, 幼若な B 細胞表 面にも発現する [7]. 以上の結果より本症例はB 細胞由 来の皮膚型リンパ腫の非表皮向性型と判断された。一般 にB 細胞由来のリンパ腫と $\mathrm{T}$ 細胞由来のリンパ腫では治 療に対する応答が異なると報告されている [5]. 犬のリ ンパ腫の多くはB 細胞由来であるが，ほとんどのリンパ 腫において表現型の不均一性があることが示唆されてい る [10].しかし, 皮虐型リンパ腫においては，表皮向 性型はT細胞由来のものが多いとされているが, 非表皮 向性型では明らかではない $[6,4]$.

犬の化学療法は近年急速に進歩し, 多中心型リンパ腫 においては長期生存も期待できるようになってきたが, 皮膚型リンパ腫をはじめ，ほかのリンパ腫では同じB 細 胞由来のものでも予後不良であると報告されている $[7]$.

以上，本症例における腫瘍細胞の由来およびその他の 特徵を明らかにしたことは，今後の皮膚型リンパ腫にお ける診断および治療法を確立する上で貴重な情報となり うるものと思われた。 


\section{田村一朗 藤田桂一 岡村 優 他}

稿を終えるにあたり，本症例に対する各検査にご指導，ご協 力をいただいた日本獣医畜産大学獣医畜産学部獣医学科獣医臨 床病理学教室の平田雅彦先生に深謝する。

$$
\text { 引用文 献 }
$$

[1] Birchard SJ, Sherding RG : サウンダース 小動物臨 床マニュアル, 長谷川篤彦訳, 第 1 版, 218 , 文永堂出 版, 東京 (1997)

[2] Dorn CR, Taylor DON, Schneider R : Natl Cancer Inst, 40, 307-318 (1968)

[3 ] Goldschmidt MH : 犬と猫の皮膚腫瘍, 後藤直影訳, 第 1版, 249-261, 学空社, 東京 (1994)

[4] Kwochka KW : Contemporary Issues in Small Animal Practice, 195-212, Churchill-Livingstone, New York (1986)
[5] Levine AM, Taylor CR, Schneider DR : Blood, 58, 52-61 (1981)

[6] Moor PF, Olivry T, Naydan D : Am J Pathol, 144, 421-429 (1994)

[7] Olivry T, Moore PF, Naydan DK, Danilenko DM, Affolter VK : Arch Dermatol Res, 287, 186-192 (1995)

[8] Raskin RE : The Veterinary Clinics Of North Ameri$\mathrm{ca}$ ，獣医臨床シリーズ 1988 年版 Vol 26（5)，最新の 臨床病理, 橋本 晃他訳, 第 1 版, 51-65, 学空社, 東 京 (1998)

[9] Theilen GR : 獣医臨床腫瘍学, 竹内 啓訳, 第 1 版, 263-273, 学空社, 東京 (1985)

[10］Withrow SJ, MacEwen EG : 小動物の臨床腫瘍学, 加 藤 元，他訳，第 1版，387-401，文永堂出版，東京 (1995)

Cutaneous B-cell Lymphoma in a Young Dog

Ichiro TAMURA* ${ }^{* \dagger}$, Keiichi FUJITA, Masaru OKAMURA, Sachiko HANADA, Hiroyuki TAKAYANAGI, Mami MITSUMURA, Hozumi YAMAMURA and Takeo SAKAI

* Fujita Animal Hospital, 1-2-53 Kasuga, Ageo 362-0074, Japan

\section{SUMMARY}

Several cutaneous tumors were observed on the back and abdomen of a 2-year-old mongrel male dog. On the basis of histopathological, immunohistochemical, cytochemical, and flow-cytometry analyses for cellsurface antigens, the tumors were diagnosed as nonepitheliotrophic, cutaneous, B-cell lymphoma.

- Key words : B-cell lymphoma, cutaneous lymphoma, dog.

$\dagger$ Correspondence to : Ichiro TAMURA (Fujita Animal Hospital)

1-2-53 Kasuga, Ageo 362-0074, Japan

TEL $048^{-775-3338 \quad F A X ~ 048-776-2337}$

J. Jpn. Vet. Med. Assoc., 54, $208 \sim 211$ (2001)

\section{日本小動物獣医学会誌編集委員会委員}

【編 集 委 員】

()代田 欣二（麻布大学生物科学総合研究所）

○萩尾 光美 (宮 崎 大 学 農 学 部) 甲斐知惠子 (東京大学医科学研 究所) 佐藤れえ子 (岩手大学農学 部) 武藤 眞 (麻布大学 獣医学部)

【専門審査委員】

新城 敏晴 (宮崎大学 農 学 部) 神尾次彦 (家畜衛生試験場細菌・寄生虫病研究部) 杉本 千尋（帯広畜産大学原虫病研究センター） 小久江栄一 (東京農 工大学農 学 部) 田浦 保穂（山口大学農学部）
伊藤 壽啓 (鳥 取大学 農 学 部)

高鳥 浩介 (国立医薬品食品衛生研究所衛生微生物部)

辻本元 (東京大学大学院農学生命科学研究科)

藤瀬 浩 (麻布大学 獣医 学 部)

【編 集 幹 事】

町田登 (東京農工大学農 学 部)

（@委員長，○副委員長）
編集人日本小動物 獣医学会 会長 山根義 久 